TEME, г. XLIV, бр. 2, април - јун 2020, стр. 355-380

Оригинални научни рад https://doi.org/10.22190/TEME180206031G

Примљено: 6. 2. 2018.

UDK 37.014.22

Ревидирана верзија: 1. 11. 2019.

Одобрено за штампу: 15. 4. 2020.

\title{
CRITICAL THINKING SKILLS OF THIRD GRADE SECONDARY SCHOOL STUDENTS \\ AS A COMPONENT OF THEIR FUNCTIONAL LITERACY ${ }^{a}$
}

\author{
Tatjana Glušac ${ }^{1 *}$, Vesna Pilipović ${ }^{1}$, Mira Milić ${ }^{2}$ \\ ${ }^{1}$ Union University in Belgrade, Faculty of Law and Business Studies \\ Lazar Vrkatić, Serbia \\ ${ }^{2}$ University of Novi Sad, Faculty of Sport and Physical Education, Novi Sad, \\ Serbia \\ *tatjana.glusac@gmail.com
}

\begin{abstract}
The modern education perspective views functional literacy, along with critical thinking as its component, as an essential academic skill without which an individual's desired academic, personal, and professional success cannot be attained. The aim of this paper is to present part of the results obtained through investigating the cognitive reasoning skills of third grade secondary school students $(\mathrm{N}=703)$ in Novi Sad, Serbia, through investigating their functional literacy in the Serbian language. Those students are about either to enter the job market or pursue their further education and will need both functional literacy and critical thinking skills to a large extent. A questionnaire comprised of 20 questions was constructed to assess the students' prose and document literacy. The gathered data were analyzed using SPSS 15 and the findings indicate that the level of the respondents' functional literacy is at a disquieting level and that all of them, irrespective of the type of school they attend, can perform lower-order cognitive processes much more successfully than higher-order ones.
\end{abstract}

Key words: functional literacy, cognitive reasoning, third-grade secondary school students, document literacy, prose literacy

\footnotetext{
a The paper is based on a research project that was financed by the Provincial Secretariat for Science and Technological Development in 2014/2015. The name of the funded project was "Development of Functional Literacy" (No. 114-451-1279/2014-01).
} 


\title{
КРИТИЧКО МИШЉЕЊЕ УЧЕНИКА ТРЕЪЕГ РАЗРЕДА СРЕДЫИХ ШКОЛА КАО КОМПОНЕНТА ЊИХОВЕ ФУНКЦИОНАЛНЕ ПИСМЕНОСТИ
}

\begin{abstract}
Апстракт
Савремено образовање сврстава функционалну писменост, заједно са критичким мишљењем као њеним саставним елементом, у кључне академске вештине без којих појединац не може остварити жељени академски, лични и професионални успех. Циљ овог рада је да се прикаже део резултата који се тичу когнитивних способности ученика трећих разреда средњих школа у Новом Саду $(\mathrm{N}=703)$, добијених истраживањем њихове функционалне писмености на српском језику. Ови ученици ће ускоро или ући на тржиште рада или ће наставити своје образовање, па ће им у великој мери бити потребни и функционална писменост и критичко мишљење. За потребе истраживања сачињен је упитник од 20 питања, којима су испитивана прозна и документацијска писменост ученика. Прикупљени подаци анализирани су помоћу пакета СПСС 15, а указују на чињеницу да је ниво функционалне писмености испитаника забрињавајући и да сви они, без обзира на врсту школу коју похађају, успешније извршавају когнитивне радње нижег нивоа у односе на оне вишег нивоа.
\end{abstract}

Кључне речи: функционална писменост, когнитивне способности, ученици трећег разреда средње школе, документацијска писменост, прозна писменост

\section{INTRODUCTION}

Until the computer became easily accessible to many, the primary goal of education had been the transmission of knowledge from the educator to the student. The very moment information became available to a large number of people at the click of a mouse, the role of the school changed drastically. The school ceased to be the provider of knowledge, but grew into the enabler of students to manipulate inexhaustible pools of information. This has invoked a change in the term literacy, which no longer presupposes only one's ability to read and write, even though this is still a privilege in many struggling economies, but the ability to manipulate information and apply it, commonly referred to as functional literacy.

The contemporary education perspective views functional literacy (FL), along with critical thinking (CT) as its component (Pilipović and Glušac, 2017, p. 327; Information Literacy Group, 2018, p. 3), as an essential academic skill without which an individual's desired academic, personal, and professional success cannot be attained. Many countries have made both FL and CT educational priorities, but some of them have overlooked the need to ensure adequate methods for teaching them. The aim of this paper, thus, is to show the results of a research study examining CT skills as part of the FL of third-grade secondary school students in Novi Sad. The goal of the research was to discover whether these students already possess the much needed skills of CT and FL, or if ways to help them hone these skills must still be 
devised so that they can achieve even better academic results and adequately respond to the needs of the contemporary world once they complete their secondary school education.

\section{THEORETICAL BACKGROUND}

Two relatively complex terms - functional literacy and critical thinking - will be presented in the following sections as they are the cornerstones of this paper.

\subsection{Functional Literacy: Concept and Types}

Before the 1950s literacy related to one's ability to read and write and denoted skills that were reserved for a privileged number of people. From the 1950s on, the term comprised reading, writing, listening, and speaking and pertained to a greater number of people. Today, literacy is no longer understood as a capability possessed by a certain number of individuals, but is recognized as a basic human right (and has been since the establishment in 1948 of the Universal Declaration of Human Rights), giving every individual the right to be equipped, at the very least, with the skills necessary to both receive and send a message.

UNESCO was the first to emphasize the importance of literacy and among the first to define it. Its first definition included only the skills of reading and writing (UNESCO, 1978, p. 3) and this denoted one's elementary literacy. Over time, it became obvious that elementary literacy was no longer sufficient for one's successful living; hence, it began to be viewed as a cluster of different skills or literacies necessary for an individual's development. UNESCO (2005, p. 154) then proposed the following definition of FL:

"A person is functionally literate who can engage in all those activities in which literacy is required for effective functioning of his group and community and also for enabling him to use reading, writing and calculation for his own and the community's development."

Similarly, OECD (2000, p. x) defines FL as the ability to understand information for personal, business, and social purposes, emphasizing one's ability to employ this information. As areas of human activity have expanded dramatically from the second half of the previous century, terms such as 'visual literacy', 'media literacy', 'scientific literacy', and 'information literacy' have made their way into some scholars' and countries' definitions, signaling new areas in which people need be literate.

Numerous definitions of FL vary in the way they define the skills that literacy is composed of, which is probably the result of the different economic, political, social, and other conditions of the countries that 
produced these definitions (OECD, 2000, p. 153-159). Despite such inconsistencies, all the contemporary definitions have one important thing in common - they emphasize the person's ability to apply the knowledge and skills that literacy is made of; for this reason, modern-day literacy is most commonly referred to as functional literacy and is based on one's ability to think critically (Pilipović and Glušac, 2017, p. 327). FL has become so important to an individual's life that it no longer presents a personal or an institutional goal, but a national priority of many countries and is thus usually defined, and its implementation regulated, in a document known as a national strategy (Glušac, Pilipović and Popović 2015, p. 42).

Since it has been made an educational priority worldwide, there is a growing need for FL to be assessed, for which reason its component parts must be singled out. Towards this purpose, OECD (2000, p. x) proposed assessing document, prose, and quantitative literacies for people aged 16 and over as these are the basic skills required for leading a successful personal and professional life today. These literacies are believed to be developed gradually throughout a person's life and they heavily influence one's health, social participation, employment prospects, political engagement, cultural and environmental awareness, and the like. The level of an individual's literacy directly impacts all spheres of his/her life and thus reflects on the entire society in which the person lives.

Document literacy (DL) is defined as "the knowledge and skills required to locate and use information contained in various formats, including job applications, payroll forms, transportation schedules, maps, tables and charts" (OECD, 2000, p. x). This literacy enables an individual to take care of his/her health, perform various transactional activities, travel (Cohen and Snowden, 2008, p. 9), and understand and manipulate information that is presented not only in a textual form, but also in the form of tables, graphs, maps, etc.

Prose literacy (PL) relates to "the knowledge and skills needed to understand and use information from texts including editorials, news stories, brochures and instruction manuals" (OECD, 2000, p. x). In other words, this literacy denotes a person's ability to process a longer piece of text, understanding not only its surface meaning, but also its less obvious messages.

According to OECD (2000, p. x), quantitative literacy (which was not part of the research this paper is based on) comprises the following:

"The knowledge and skills required to apply arithmetic operations, either alone or sequentially, to numbers embedded in printed materials, such as balancing a checkbook, figuring out a tip, completing an order form or determining the amount of interest on a loan from an advertisement." 


\subsection{Critical Thinking as a Component Part of Functional Literacy}

Cognitive reasoning underpins all activities we perform on a daily basis for both personal and professional reasons. In their investigation of different types of literacies, a number of authors (e.g. Avgerinou and Ericson, 2002; Feuerstein, 1999; Johnson, 2007; Kong, 2014; Vieira and TenreiroVieira, 2016; Ward, 2006), without exception, have addressed the issue of critical thinking as an inextricable component of literacy. Along the same lines, whenever one reads any kind of text, searches for information, or manipulates it in a certain way as part of our document or prose literacy, it is inherently the case that one applies different cognitive reasoning processes.

Cognitive reasoning encompasses more and less complex actions which are graded and known as Bloom's Taxonomy of the Cognitive Domain (Bloom et al., 1956). The Taxonomy comprises six successive stages: knowledge, comprehension, application, analysis, synthesis, and evaluation. Each level involves different cognitive activities and is usually described by a list of action verbs suggesting actions a student can perform at each level. Also, each level is cumulative in nature, thus involving all the preceding levels (Bloom et al., 1956, p. 18). For instance, knowledge represents one's ability to recall, recognize, name, state, list, label, etc. Comprehension is represented through the student's ability to translate, comprehend, interpret, summarize information, and the like. At the level of application, one can select, transfer, use, and compute or apply data to solve a problem or do a task. The analysis level requires a person to, among other actions, distinguish, classify, relate, analyze, categorize, and compare assumptions and evidence. Synthesis relates to one's capability to integrate and combine ideas into a new product, and is thus usually described by verbs such as create, design, hypothesize, invent, develop, etc. The highest level of cognitive processing is evaluation, which presupposes assessing, appraising, and critiquing information. The first three cognitive processes are typically referred to as lower-order thinking skills, whereas the remaining three are labeled higher-order thinking skills, signifying critical thinking.

Based on probably the most comprehensive definition of CT provided by Glaser (1941), CT pertains to one's ability to understand and manipulate information of varying difficulty presented in different ways through performing a number of cognitive activities. Still, there are numerous definitions of $\mathrm{CT}$, each viewing it from a slightly different perspective, yet they all have several premises in common: (1) CT relates to a number of cognitive processes an individual performs when processing information, (2) it requires a number of intellectual and personal traits (humility, inquisitiveness, fair-mindedness, perseverance, tolerance, etc.), (3) it can be learned and improved, and (4) it is paramount for thriving in today's world.

Pursuant to their definitions given in Section 2.1, document and prose literacy relate to understanding, analyzing and manipulating information presented in textual and other forms (graph, table, chart, etc.). Therefore, the 
level of one's DL is evident through the ability to understand and manipulate information presented in some other form, rather than textual, which may include charts, graphs, tables, maps etc. In its description of the five levels of this type of literacy, OECD (2000, p. 97-99) states that to solve tasks in this field, one needs to exhibit cognitive capabilities to match information, make inferences, apply information, synthesize, analyze, compare, contrast and the like. On the other hand, OECD (2000, p. 94-97) lists the following cognitive activities underpinning PL: literal or synonymous matching, inference (lowor high-level), locating information, integration of information, comparison, and contrast. The difficulty of these operations is influenced by certain text characteristics such as type, length, density, content and the use of structural and organizational aids (OECD, 2000, p. 94), the way questions are formulated, and the number of operations required for successful completion of a given task. Clearly, performing any of the operations mentioned involves performing a number of other, closely related, operations.

The mastery of DL and PL calls for the ability to perform a number of cognitive activities that constitute one's thinking capacity, for which reason it is seen as an inextricable component part of FL. By improving their students' literacies, teachers facilitate their confidence and ability to audaciously manipulate the information they have at hand.

\section{RESEARCH}

The aim of this research was to assess the functional literacy (document and prose) of third-grade students attending all secondary schools in Novi Sad through assessing their cognitive reasoning skills. As the last PISA results for Serbia were rather alarming (Pavlović-Babić and Baucal, 2013), the researchers' aim was to determine whether the level of students' FL has reached a satisfactory level at the age of 16, particularly as some students (those attending three-year programs in vocational schools) would be in the last year of schooling and would soon be entering the job market. Moreover, those attending 4-year programs would likely soon be applying for admission to universities and would need a range of academic skills contained in both prose and document literacy.

\subsection{Research Method}

The research was conducted in March and April 2015. Each class of surveyed students was given 45 minutes to complete the questionnaire and did so during one of their regular classes.

A total of 703 third-year secondary school students from all sixteen secondary schools in Novi Sad were surveyed. For the purposes of this paper, the schools are divided into three groups: high schools $(290$ students), vocational schools (350 students), and art schools (63 students). Some students of vocational schools attended three-year programs, while 
others attended four-year programs. All the students from high and art schools were enrolled in four-year programs.

The researchers constructed a questionnaire comprising 20 questions, ten testing DL and ten PL (Savković, 2015, p. 145-153). As the aim of the research was to assess the students' functional literacy in the Serbian language, all the questions were in Serbian. As the researchers are faculty of the Department of English, it seemed reasonable to test only language-related types of functional literacy and not quantitative. The survey was anonymous. The measuring instrument was pilot tested to ensure satisfactory characteristics.

The questions were of varying difficulty (OECD, 2000, p. 94-99) and required respondents to perform a number of more or less complex cognitive activities. The tasks were designed carefully in that they tackled topics of immediate interest to the respondents (taking the bus, traveling by plane, entering university, applying for a scholarship, reading a newspaper article, reading an excerpt from a home reading, etc.). First, the respondents were asked to read a short passage or to look at numerical data and provide an answer to the question that followed by circling one out of five provided answers. Each question had only one correct answer, three answers were distractors, and the fifth was 'I don't know' and was aimed at signaling the lack of the student's skills to perform the task.

The gathered data were analyzed using SPSS 15 and for the purposes of this paper they will be presented as correct and incorrect answers for each question for each of the three types of schools. Moreover, a short description of each of the questions will be provided in the tables containing the findings, whereas the original questionnaire is given in the Appendix.

For each of the 20 questions the authors singled out all cognitive activities the students needed to perform in order to answer a particular question. By doing so, the researchers attempted to assign each question a corresponding level of the Taxonomy and determine its level of CT pursuant to the definitions of the levels of difficulty proposed by OECD (2000, p. 95-99).

As the time to conduct the research was short and limited (45 minutes for each class), the survey could only contain closed questions, which ruled out the possibility to include questions at the last two levels of CT - synthesis and evaluation - since they require production on the part of the student and must be in the form of open-ended questions.

\subsection{Results}

3.2.1. Document literacy. Out of the ten questions examining DL, 4 questions were at the understanding level of the Taxonomy (Qs 5, 10, 11 and 17), 2 were at the applying level (Qs 2 and 19), and 4 were at the analyzing level (Qs 4, 7, 8 and 14). The findings presented in Table 1 clearly indicate that the students perform differently when doing tasks at the same level of the Taxonomy. More precisely, high school students were 
fully successful in doing tasks at the level of understanding, except for task 11. Art school students did well in tasks 5, 11 and 17, while those enrolled in vocational schools found it difficult to perform tasks at this level, as the only question to which they gave more positive than negative answers was question 17.

Table 1. Results in document literacy

\begin{tabular}{|c|c|c|c|c|}
\hline Number and type of question & Level & Type of school & Correct & Incorrect \\
\hline \multirow{4}{*}{$\begin{array}{l}2 \\
\text { choosing an appropriate bus } \\
\text { from a bus schedule }\end{array}$} & \multirow{4}{*}{ apply } & High Schools & 165 & 125 \\
\hline & & Vocational Schools & 136 & 214 \\
\hline & & Art Schools & 42 & 21 \\
\hline & & Total & 343 & 360 \\
\hline \multirow{4}{*}{$\begin{array}{c}4 \\
\text { understanding criteria for } \\
\text { applying for a scholarship }\end{array}$} & \multirow{4}{*}{ analyze } & High Schools & 126 & 164 \\
\hline & & Vocational Schools & 126 & 224 \\
\hline & & Art Schools & 24 & 39 \\
\hline & & Total & 276 & 427 \\
\hline \multirow{4}{*}{$\begin{array}{l}5 \\
\text { understanding criteria for } \\
\text { applying for a scholarship }\end{array}$} & \multirow{4}{*}{ understand } & High Schools & 208 & 82 \\
\hline & & Vocational Schools & 169 & 181 \\
\hline & & Art Schools & 34 & 29 \\
\hline & & Total & 411 & 292 \\
\hline \multirow{4}{*}{$\begin{array}{c}7 \\
\text { understanding statistical } \\
\text { data presented in a table }\end{array}$} & \multirow{4}{*}{ analyze } & High Schools & 87 & 203 \\
\hline & & Vocational Schools & 76 & 274 \\
\hline & & Art Schools & 14 & 49 \\
\hline & & Total & 177 & 526 \\
\hline \multirow{4}{*}{$\begin{array}{c}8 \\
\text { understanding statistical } \\
\text { data presented in a table }\end{array}$} & \multirow{4}{*}{ understand } & High Schools & 188 & 102 \\
\hline & & Vocational Schools & 172 & 178 \\
\hline & & Art Schools & 35 & 28 \\
\hline & & Total & 395 & 308 \\
\hline \multirow{4}{*}{$\begin{array}{l}10 \\
\text { understanding criteria for } \\
\text { admission to a faculty }\end{array}$} & \multirow{4}{*}{ understand } & High Schools & 164 & 126 \\
\hline & & Vocational Schools & 152 & 198 \\
\hline & & Art Schools & 26 & 37 \\
\hline & & Total & 342 & 361 \\
\hline \multirow{4}{*}{$\begin{array}{l}11 \\
\text { understanding criteria for } \\
\text { admission to a faculty }\end{array}$} & \multirow{4}{*}{ understand } & High Schools & 144 & 146 \\
\hline & & Vocational Schools & 129 & 221 \\
\hline & & Art Schools & 19 & 44 \\
\hline & & Total & 292 & 411 \\
\hline \multirow{4}{*}{$\begin{array}{l}14 \\
\text { understanding instructions } \\
\text { for taking a medicine }\end{array}$} & \multirow{4}{*}{ analyze } & High Schools & 71 & 219 \\
\hline & & Vocational Schools & 74 & 276 \\
\hline & & Art Schools & 14 & 49 \\
\hline & & Total & 159 & 544 \\
\hline \multirow{4}{*}{$\begin{array}{l}17 \\
\text { selecting a flight according } \\
\text { to the given criterion }\end{array}$} & \multirow{4}{*}{ understand } & High Schools & 246 & 44 \\
\hline & & Vocational Schools & 260 & 90 \\
\hline & & Art Schools & 42 & 21 \\
\hline & & Total & 548 & 155 \\
\hline \multirow{4}{*}{$\begin{array}{l}19 \\
\text { understanding information } \\
\text { necessary to fill in a form }\end{array}$} & \multirow{4}{*}{ apply } & High Schools & 107 & 183 \\
\hline & & Vocational Schools & 88 & 262 \\
\hline & & Art Schools & 12 & 51 \\
\hline & & Total & 207 & 496 \\
\hline
\end{tabular}


High school and art school students showed equal capability in doing certain tasks at the application level, as both had more correct than incorrect answers to question 2. However, all students showed an inability to perform the skill of application in question 19.

The level of analyzing was assessed through 4 questions and all types of respondents had more incorrect than correct answers in three tasks - 4, 7 and 14. High school and art school students scored more correct than incorrect answers only for question 8 .

The results pertaining to the level of understanding show that different students exhibit differing capabilities when doing tasks at this level. Namely, question 5 required students to perform the simple cognitive activity of locating an explicitly given piece of information in a longer text and it is evident that high and art school students indeed could. However, when they were required to infer, as the information was not explicitly offered (Q 11), all types of respondents gave more incorrect than correct answers. Furthermore, interpreting meaning seems to be problematic for students attending vocational and art schools, as question 10 required locating information and interpreting the meaning of a punctuation mark (slash) in order to demonstrate understanding. Questions 10 and 11 were related to a text dealing with necessary documents for enrolling in a university. On the other hand, when students were asked to choose an obvious answer by comparing small pools of numerically given data $(\mathrm{Q}$ 17), all types of students were capable of performing the task. The data were related to the times of flights to a particular destination.

At the level of applying, only high and art school students performed satisfactorily with respect to question 2, which required them to choose an appropriate bus while taking into account several factors. On the other hand, all types of respondents had more incorrect than correct answers in question 19, in which their previously acquired knowledge needed to be used in order to complete the task - completing a form for obtaining parents' consent.

In performing the tasks related to analyzing, all types of respondents scored low on tasks 4 and 14, which required inferring through considering several pieces of information contained in different parts of a longer text related to documents needed for applying for a scholarship and taking medicine, respectively. Also, they scored low on question 7 in which they needed to consider a large number of numerically presented data concerning statistics. Contrastingly, high and art school students scored well on question 8 in which they needed to process a smaller amount of numerically presented information.

3.2.2. Prose literacy. As for PL, out of the ten questions aimed at its assessment, 1 question evaluated knowledge (16), 6 questions were at the understanding level $(1,3,6,12,13$ and 20), and 3 questions were aimed at assessing analyzing $(9,15$ and 18). All types of respondents performed well 
in answering question 16, requiring students to do a number of cognitive actions qualified as 'knowledge'. Questions examining the students' ability to understand a prose text revealed that all schools' students were equally unsuccessful in understanding the text in questions 3,12 and 13. On the other

Table 2. Results in prose literacy

\begin{tabular}{|c|c|c|c|c|}
\hline $\begin{array}{c}\text { Number and type of } \\
\text { question }\end{array}$ & Level & Type of school & Correct & Incorrect \\
\hline 1 & \multirow{4}{*}{ understand } & High Schools & 245 & 45 \\
\hline \multirow{3}{*}{$\begin{array}{l}\text { making a conclusion based } \\
\text { on the information from a } \\
\text { research article }\end{array}$} & & Vocational Schools & 229 & 121 \\
\hline & & Art Schools & 50 & 13 \\
\hline & & Total & 524 & 179 \\
\hline \multirow{4}{*}{$\begin{array}{c}3 \\
\text { choosing a synonym for a } \\
\text { word from a text on } \\
\text { neoliberalism }\end{array}$} & \multirow{4}{*}{ understand } & High Schools & 81 & 209 \\
\hline & & Vocational Schools & 52 & 298 \\
\hline & & Art Schools & 10 & 53 \\
\hline & & Total & 143 & 560 \\
\hline \multirow{4}{*}{$\begin{array}{l}6 \\
\text { understanding the point of a } \\
\text { newspaper article on culture }\end{array}$} & \multirow{4}{*}{ understand } & High Schools & 212 & 78 \\
\hline & & Vocational Schools & 214 & 136 \\
\hline & & Art Schools & 44 & 19 \\
\hline & & Total & 470 & 233 \\
\hline 9 & \multirow{4}{*}{ analyze } & High Schools & 112 & 178 \\
\hline \multirow{3}{*}{$\begin{array}{l}\text { understanding the attitude of } \\
\text { one character towards the } \\
\text { other in a literary text }\end{array}$} & & Vocational Schools & 136 & 214 \\
\hline & & Art Schools & 32 & 31 \\
\hline & & Total & 280 & 423 \\
\hline 12 & \multirow{4}{*}{ understand } & High Schools & 52 & 238 \\
\hline \multirow{3}{*}{$\begin{array}{l}\text { understanding a research } \\
\text { article explaining the visibility } \\
\text { of colors on a TV screen }\end{array}$} & & Vocational Schools & 47 & 303 \\
\hline & & Art Schools & 8 & 55 \\
\hline & & Total & 107 & 596 \\
\hline \multirow{4}{*}{$\begin{array}{l}13 \\
\text { understanding a metaphor in } \\
\text { a newspaper article on } \\
\text { hyper-information }\end{array}$} & \multirow{4}{*}{ understand } & High Schools & 27 & 263 \\
\hline & & Vocational Schools & 40 & 310 \\
\hline & & Art Schools & 14 & 49 \\
\hline & & Total & 81 & 622 \\
\hline \multirow{4}{*}{$\begin{array}{l}15 \\
\text { understanding the point of a } \\
\text { literary text }\end{array}$} & \multirow{4}{*}{ analyze } & High Schools & 37 & 253 \\
\hline & & Vocational Schools & 28 & 322 \\
\hline & & Art Schools & 9 & 54 \\
\hline & & Total & 74 & 629 \\
\hline \multirow{4}{*}{$\begin{array}{c}16 \\
\text { understanding individual } \\
\text { information in a literary text }\end{array}$} & \multirow{4}{*}{ knowledge } & High Schools & 239 & 51 \\
\hline & & Vocational Schools & 230 & 120 \\
\hline & & Art Schools & 52 & 11 \\
\hline & & Total & 521 & 182 \\
\hline \multirow{4}{*}{$\begin{array}{c}18 \\
\text { understanding similarities } \\
\text { between two concepts in a } \\
\text { scientific article }\end{array}$} & \multirow{4}{*}{ analyze } & High Schools & 205 & 85 \\
\hline & & Vocational Schools & 166 & 184 \\
\hline & & Art Schools & 23 & 40 \\
\hline & & Total & 394 & 309 \\
\hline \multirow{4}{*}{\multicolumn{2}{|c|}{$\begin{array}{l}20 \\
\text { understanding a metaphor in understand } \\
\text { a political article }\end{array}$}} & High Schools & 238 & 52 \\
\hline & & Vocational Schools & 227 & 123 \\
\hline & & Art Schools & 41 & 22 \\
\hline & & Total & 506 & 197 \\
\hline
\end{tabular}


hand, all types of students did equally well in tasks 1, 6 and 20. The students' ability to analyze a prose text was assessed in questions 9,15 and 18 and all types of respondents had more incorrect than correct answers in the first two questions, whereas only high school students were successful pertaining to question 18.

All types of students performed well on the first-level question (knowledge). They were asked to locate an explicitly stated piece of information in a two-sentence excerpt from a novel (Q 16).

At the level of understanding, the students performed well in answering questions requiring them to locate an explicitly given piece of information (Q 1), compare and relate similar pieces of information (Q 6), and infer the meaning of a widely used proverb (Q 20). The first of these three questions was related to a short paragraph dealing with health, the second was related to culture, while question 20 was a short paragraph from a daily newspaper featuring politics. However, at the same level, all types scored low when asked to make an inference on the basis of a one-sentence newspaper article on the neoliberal order (Q 3), compare and contrast different pieces of information in a slightly longer passage dealing with sports-related science (Q 12), or infer the meaning of a saying (Q 13).

At the fourth level of the Taxonomy (analyzing), the students did not respond satisfactorily to questions asking them to discriminate, estimate, and compare information in a longer excerpt from a novel (Q 9) or to prioritize and focus in a short excerpt from another novel (Q 15). In contrast, only high school students had more correct than incorrect answers related to question 18 , in which they were required to connect information in order to make a conclusion regarding a longer passage involving biology.

\subsection{Discussion}

Generally speaking, the respondents' level of DL is higher than their PL (3,150 and 3,100 correct answers, respectively), high school students being most successful, followed by art, and then vocational school students. This finding corroborates those of Krnjajić, Stepanović and Pavlović Babić (2011, p. 278) showing that the type of school, in addition to one's school grades and parents' level of education, impacts one's reading literacy. However, a careful analysis of the findings obtained through our research yields somewhat different insights.

The findings related to DL reveal that all types of students have problems with understanding different layers of a text as they all scored low on question 11, which required the making of a deduction based on information provided in a three-paragraph document. While high and art school students did show the ability to locate a piece of information in a longer text (Q 5), all types of respondents lack the skill of integrating information scattered in a text in order to make an inference (Qs 4 and 14). In other words, high and art school students could process longer 
texts, but only for those tasks requiring the location of information. When it comes to performing more complex cognitive activities requiring manipulation of data, all types of students were incapable of processing longer texts. The same applies to numerically presented data. When asked to choose an answer by comparing just a few pieces of numeric data, they all performed well. However, when required to compare and contrast a somewhat larger pool of numeric data (Q 8), only high and art school students could manage. When asked to process a large pool of numeric data (Q 7), all types of students proved incapable.

Even though the researchers tried to select topics that would be of immediate interest to the respondents, the type of the material on which DL questions were based did not significantly impact the students' performance. Namely, vocational school students appeared to be unaccustomed to traveling by bus (Q 2), while all students seemed to be familiar with traveling by plane (Q 17). Moreover, students could not understand instructions for taking medicine (Q 14), whereas only high and art school students displayed the ability to respond adequately to an application for a scholarship or to read statistics. Only high school students demonstrated an understanding of the criteria to be met when applying to a university.

When considering their cognitive reasoning capabilities, all students are more or less successful in understanding textual or numeric data (high school students being most successful, followed by art, and then vocational students). The low-order cognitive activity of application seems to be problematic for most students, as in answering questions 2 and 19 more negative than positive responses were recorded. The higherorder thinking skill of analysis was tested in three tasks (Qs 4, 7 and 14) and the results indicate all students having problems in solving tasks at this level of complexity.

The findings pertaining to PL indicate that students have problems with processing longer prose texts. Namely, when asked to read a short passage (1-3 sentences), all types of students could locate an obvious answer (Qs 1, 6 and 16). However, when required to understand the underlying message of a short text (Qs 3, 13 and 15), they proved incapable. Only in question 20, which required reading a two-sentence paragraph from a newspaper article on politics, were students able to infer the meaning of a widely used proverb. When they were asked to read a longer passage (Qs 9 and 12), the students could not provide the correct answer, even in order to demonstrate understanding (Q 12). Only high school students scored well on question 18 pertaining to reading a longer passage on biology.

Regarding the type of text, the students seemed well accustomed to reading newspapers, as all types scored high on questions 1, 6 and 20, covering topics such as health, history, and politics. However, they appeared least familiar with reading science-related texts, as all types scored low on question 12, dealing with sports-related science. Only high 
school students scored well on the science text dealing with biology (Q 18). The lack of students' ability to comprehend texts in the domain of science is rather alarming since a research study conducted among Serbian university students in all fields of study showed that they do read texts from their chosen fields of study to a large extent (Perčić and Vukadinović, 2019, p. 425), most probably as a requirement. When it comes to reading literature, all students could understand surface meaning (Q 16), but not the underlying layers of a text or implied meanings (Qs 9 and 15).

With regard to their cognitive reasoning skills, all types of students seem to possess the first-level skills (knowledge) and the ability to understand surface meaning (Qs 1 and 6). When it comes to understanding other layers of a text (Qs 3, 12 and 13), they appear to lack adequate skills. Moreover, the students' ability to analyze a prose text needs to be honed, as in all but one question (Q 18) requiring this higher-order cognitive reasoning skill the students scored far more negative than positive answers.

\section{CONCLUSION}

The gathered findings indicate that the cognitive reasoning skills of third-grade secondary school students are worrying. While most students seem capable of performing the lower-order thinking skills of remembering and understanding, the majority of them have problems when processing information at the levels of application and analysis. Moreover, the research revealed that the students struggle with processing a larger number of either textual or numeric data, as well with understanding underlying messages and implied meanings. Furthermore, most respondents can understand short passages from newspapers, but they struggle with understanding sciencerelated texts and literature. All this implies that our students do not possess adequate CT skills necessary for either entering the business world after their secondary school education or for pursuing college education. As the level of one's literacy strongly impacts different domains of an individual's life, these findings suggest that the respondents' future is not very promising unless they are immediately supported in developing the skills they need for life.

The formation of reading habits begins very early in one's life. The parents' attitude to books and reading is thus an essential component in forming the reading habit (Stojanović and Purić, 2014), while its further development depends on the view of the importance of reading each school designates. It is the teachers' attitude to information and its different sources, as well as their skill in using those sources as a teaching tool, that stimulates the thirst for knowledge in their students. In their contemplation on the role of text in language and literature teaching, Cvetanović, Stojanović and Mišić (2017, p. 645) emphasize that reading different genres of texts contributes to the development and improvement of students' reading habits, knowledge, and autonomous learning. According 
to the same authors $(2017$, p. 648), reading a text should not presuppose students' ability to regurgitate it; they need to be taught and motivated to read it, think over it, and make decisions/inferences regarding it - only then will they finally be able to apply the newly acquired information in novel situations. Only in such a way are students' cognitive capacities stimulated and their knowledge transformed from the merely reproductive to the functional. The same recommendations regarding the use of texts in language education put forward by Cvetanović, Stojanović and Mišić (2017) can apply to all school subjects: students should be given practice in reading domain-specific texts and understanding other ways in which information is presented (graphs, tables, diagrams, etc.) through meaningful activities that do not require from them learning information by heart, but searching for it, understanding it, manipulating it, and, finally, putting it into use. Teachers of all school subjects, not language teachers alone, have a crucial role in developing the reading literacy of their students. Besides literacy, those teachers also contribute to developing students' domainspecific critical thinking skills (Pešić, 2007, p. 41) through helping them master the subject-specific materials.

A number of studies conducted in Serbia with the aim of examining teaching practices regarding CT have mostly reported teachers' positive attitude towards the teaching of CT and good teaching practices. For example, Mirkov and Stokanić (2015) discovered that primary school teachers of different subjects do engage students in discussions, problem analysis, asking questions, problem solving, etc., all of which promote their $\mathrm{CT}$. However, younger teachers were found to have a more positive view of innovative formats of work (e.g., projects and research), but they do not use them in practice (Mirkov and Stokanić 2015, p. 36). Also, Glušac and Pilipović (2016) found out that primary and secondary English language teachers make use of Socratic questioning, the technique used for investigating the nature and rationale of thinking. However, the results of a study conducted by Mirkov and Gutvajn (2014) indicated that Serbian eighth-graders were dissatisfied with the number of opportunities for developing their CT skills. Along the same lines, Glušac, Pilipović and Marčićev (2019) discovered that English language teachers in Serbia did not seem to possess adequate skills for assessing their students' progress in the acquisition of domain-specific CT skills, which is an important prerequisite for successful teaching and learning.

It goes without saying that besides parents and teachers, the school as an institution has a vital role in promoting both the literacy and critical thinking of its students. While it is still an unresolved issue whether the crucial component of literacy - critical thinking - is best taught and learned as a separate school subject or a domain-specific skill (Pešić, 2007), one thing is indisputable: critical thinking should also be developed through a myriad of extra-curricular activities (Pešić, 2007, p. 40) in school as they 
require the synthesis and application of the acquired knowledge. Moreover, many authors (e.g., Krnjajić, Stepanović and Pavlović Babić, 2011) have accentuated the quality of the school library as an important precursor of students' reading literacy. Also, the application of versatile work formats, appropriate teaching techniques, and quality assessment tools necessitate good quality professional development opportunities for teachers. Without a doubt, the creation of a positive and encouraging climate in schools in which the teaching staff, the school administration, as well as the education policy makers share the same goal - good quality education that is aligned with the needs of the contemporary society — is also a must.

\section{REFERENCES}

Avgerinou, M., \& Ericson, J. (2002). A review of the concept of visual literacy. British Journal of Educational Technology, 28(4), 280-291. doi.org/10.1111/14678535.00035.

Bloom, B., Englehart, M. Furst, E., Hill, W., \& Krathwohl, D. (1956). Taxonomy of Educational Objectives: The Classification of Educational Goals. Handbook I: Cognitive Domain. New York, Toronto: Longmans, Green.

Cohen, D., \& Snowden, J. (2008). The relations between document familiarity, frequency, and prevalence, and document literacy performance among adult readers. Reading Research Quarterly, 43(1), 9-26. doi: 10.1598/RRQ.43.1.2.

Cvetanović, Z., Stojanović, B., \& Mišić, D. (2017). Vrste tekstova u razrednoj nastavi jezika i književnosti [Types of texts in class teaching of language and literature]. Teme, XLI/3, 639-652. doi: 10.22190/TEME1703639C.

Feuerstein, M. (1999). Media literacy in support of critical thinking. Journal of Educational Media, 24(1), 43-54. doi: 10.1080/1358165990240104.

Glaser, E. (1941). An Experiment in the Development of Critical Thinking. New York: Teacher's College, Columbia University.

Glušac, T., Pilipović, V., \& Popović, D. (2015). Stepen dokumentacijske pismenosti učenika trećeg razreda srednjih škola: praktične i pedagoške implikacije [The level of third-grade secondary school students' document literacy: Practical and pedagogical implications]. In N. Savković (Ed.), Prozna i dokumentacijska pismenost učenika III razreda novosadskih srednjih škola - mapiranje problema [Prose and Documentation Literacy of Third-Grade Secondary School Students in Novi Sad - Mapping Problems] (39-58). Novi Sad: Fakultet za pravne i poslovne studije Dr Lazar Vrkatić.

Glušac, T., \& Pilipović, V. (2016). Developing critical thinking in teaching EFL through asking questions. In B. Vujin and M. Radin-Sabadoš (Eds.), English Studies Today: Words and Visions. Selected papers from "The Third International Conference English Language and Anglophone Literatures Today (ELALT 3)" (401-415). Novi Sad: Faculty of Philosophy.

Glušac, T., Pilipović, V., \& Marčićev, N. (2019). Analysis of English language test tasks for seventh- and eighth-graders in Serbia according to Bloom's Taxonomy. Nastava i vaspitanje, 68(1), 35-50. doi:10.5937/nasvas1901035G.

Information Literacy Group. (2018). CILIP Definition of Information Literacy 2018. London: The Library and Information Association. 
Johnson, G. M. (2007). Functional internet literacy: Required cognitive skills with implications for instruction. E-Learning, 4(4), 433-441. doi: 10.2304/elea. 2007.4.4.433.

Kong, S. C. (2014). Developing information literacy and critical thinking skills through domain knowledge learning in digital classrooms: An experience of practicing flipped classroom strategy. Computers \& Education, 78, 160-173. doi:10.1016/j.compedu.2014.05.009.

Krnjaić, Z., Stepanović, I. \& Pavlović Babić, D. (2011). Čitalačke navike srednjoškolaca u Srbiji [Reading habits of high school students in Serbia]. Zbornik Instituta za pedagoška istraživanja, 43(2), 266-282. doi: 10.2298/ZIPI1102266K

Mirkov, S., \& Gutvajn, N. (2014). How students perceive teachers' activities aimed at stimulating critical thinking. Nastava $i$ vaspitanje, 63(4), 621-636.

Mirkov, S., \& Stokanić, D. (2015). Podsticanje kritičkog mišljenja kod učenika [Inciting critical thinking of students: Teachers' attitudes and activities]. Inovacije u nastavi, XXVIII, 2015/1, 25-41.

OECD. (2000). Literacy in the Information Age. Final Report of the International Adult Literacy Survey. Paris: OECD.

Pavlović-Babić, D., \& Baucal, A. (2013). Podrži me, inspiriši me. Pisa 2012 u Srbiji: prvi rezultati [Support Me, Inspire Me. PISA 2012 in Serbia: First Results]. Beograd: Institut za psihologiju, PISA Srbija.

Perčić, K., \& Vukadinović, L. (2019). Čitalačke navike studenata u Srbiji [Reading habits amongst university students in the Republic of Serbia]. Teme, XLIII/2, 413-435. doi: 10.22190/TEME181107026P.

Pešić, J. (2007). Uloga znanja u kritičkom mišljenju [The role of knowledge in critical thinking]. Zbornik Instituta za pedagoška istraživanja, 39(1), 32-47. doi: 10.2298/ZIPI0701032P

Pilipović, V., \& Glušac, T. (2017). Čitalačka pismenost učenika srednjih škola savremeni zahtevi i dostignuća (Primer trećeg razreda novosadskih srednjih škola) [Reading literacy of secondary school students - Current requirements and achievements (Example of the third grade of secondary schools in Novi Sad)]. Zbornik Matice srpske za društvene nauke, 162, 2/2017, 317-332. doi.org/10.2298/ZMSDN1762317P.

Savković, N. (Ed.) (2015). Prozna i dokumentacijska pismenost učenika III razreda novosadskih srednjih škola - mapiranje problema [Prose and Documentation Literacy of Third-Grade Secondary School Students in Novi Sad-Mapping Problems]. Novi Sad: Fakultet za pravne i poslovne studije Dr Lazar Vrkatić.

Stojanović, B., \& Purić, D. (2014). Ljubav prema knjizi i čitanju - imperativ budućih vaspitača i učitelja [Love for books and reading - an imperative for future kindergarten educators and teachers]. Savremene tendencije $u$ nastavnim $i$ vannastavnim aktivnostima na učiteljskim (pedagoškim) fakultetima (tematski zbornik). Vranje: Učiteljski fakultet Vranje, 505-519.

UNESCO (2005). Literacy for Life. Education for All. Paris: UNESCO.

UNESCO (1978). Towards a Methodology for Projecting Rates of Literacy and Educational Attainment. Current Surveys and Research in Statistics. Paris: UNESCO.

Vieira, R. M., Tenreiro-Vieira, C. (2016). Fostering scientific literacy and critical thinking in elementary science education. International Journal of Science and Mathematics Education, 14(4), 659-680. doi: 10.1007/s10763-014-9605-2.

Ward, D. (2006). Re-visioning information literacy for lifelong meaning. The Journal of Academic Librarianship, 32(4), 396-402. doi: 10.1016/j.acalib.2006.03.006. 


\title{
КРИТИЧКО МИШЉЕЊЕ УЧЕНИКА ТРЕЪЕГ РАЗРЕДА СРЕДЫИХ ШКОЛА КАО КОМПОНЕНТА ЫИХОВЕ ФУНКЦИОНАЛНЕ ПИСМЕНОСТИ
}

\author{
Татјана Глушац ${ }^{1}$, Весна Пилиповић ${ }^{1}$, Мира Мирић $^{2}$ \\ ${ }^{1}$ Факултет за правне и пословне студије Лазар Вркатић, Београд, Србија \\ ${ }^{2}$ Универзитет у Новом Саду, Факултет спорта и физичког васпитања, Нови Сад, \\ Србија
}

\section{Резиме}

Циљ рада је да се утврди које когнитивне способности поседују ученици трећег разреда новосадских средњих школа путем процене њихове функционалне писмености. Тачније, циљ рада је да се испита да ли поменути ученици поседују способност критичког мишљења као компоненте функционалне писмености. Рад се заснива на истраживању које је превасходно испитивало нивое когнитивних способности, са примарним акцентом на више когнитивне способности, према Блумовој таксономији за когнитивни домен, кроз испитивање функционалне писмености наведених ученика.

У савременом образовању функционална писменост, заједно са својим саставним елементом - критичким мишљењем - представља суштинску академску вештину, без које је немогуће остварити било какав академски, лични или професионални циљ. Функционална писменост подразумева способност разумевања и употребе информација у различите личне, пословне или друштвене сврхе, а укључује документацијску, прозну и математичку писменост.

Да би особа имала користи од информација, она мора обавити низ једноставнијих или сложенијих когнитивних радњи с њима у вези, познатих као радње вишег и нижег реда. Ове прве обухватају активности попут памћења, разумевања и примене, док друга група укључује анализу, синтезу и евалуацију. Подела когнитивних радњи на поменутих шест нивоа позната је као Блумова таксономија за когнитивни домен и представља основу функционалне писмености, тј. обраде информација приказаних у текстуалном или неком другом облику (нпр. графикон, табела и слично).

Истраживање на којем се темељи овај рад обухватило је 703 ученика свих средњих школа у Новом Саду и за његове потребе осмишљен је упитник од 20 питања, од којих се помоћу 10 испитивала документацијска, а помоћу 10 прозна писменост. Истраживање је спроведено у периоду март-април 2015. године у оквиру пројекта „Развој функционалне писмености”, финансираног од стране Покрајинског секретаријата за науку и технолошки развој. За потребе овог рада, свако питање из упитника рашчлањено је на појединачне когнитивне радње које испитаник мора предузети како би дошао до одговора на постављено питање, а ти појединачни кораци упоређени су са глаголима којима су представљени нивои критичког мишљења по Блуму и др. (1956) како би се закључило на ком нивоу сложености је свако од питања. Додатно се свако питање упоређивало са описима пет нивоа сложености когнитивних радњи које ОЕЦД (2000) користи у својим истраживањима функционалне писмености.

Уопштено говорећи, документацијска писменост ученика новосадских средњих школа боља је у односу на прозну писменост, при чему најбоље резултате остварују ученици гимназија, потом средњих уметничких школа и, на крају, средњих стручних школа. Међутим, детаљнија анализа указује на недовољно развије- 
ну способност критичког мишљења свих средњошколаца, без обзира на тип школе коју похађају. Осим тога, резултати показују и да ученици свих школа могу наићи на проблеме при решавању задатака који захтевају когнитивне радње нижег нивоа (разумевања и примене), те да су узрочници таквих потешкоћа дужина или врста текста. Такође, резултати потврђују и неспособност средњошколаца да изврше сложеније мисаоне радње са већим бројем текстуално или нумерички приказаних података. Од укупно шест задатака којима је испитивана способност примене когнитивних радњи вишег нивоа, ученици свих школа су само на једно питање дали тек нешто већи број тачних одговора у односу на број нетачних. Примећено је и да средњошколци најлакше читају новинске чланке на одређене теме, а најслабије разумеју научне и књижевне текстове.

С обзиром на изнету тврдњу да ниво функционалне писмености и критичког мишљења у великој мери утичу на квалитет живота појединца, па и друштва у целини, резултати нашег истраживања нису охрабрујући и не обећавају блиставу будућност наших средњошколаца уколико се решењу проблема не приступи систематично и одмах.

\section{APPENDIX}

\section{UPITNIK}

Poštovani, molimo Vas da popunite Upitnik koji je anoniman, a rezultati istraživanja će se koristiti isključivo u naučnoistraživačke svrhe. Pred Vama se nalazi 20 pitanja na 9 strana, koja se odnose na razumevanje teksta. Molimo Vas da pažljivo pročitate svako pitanje i odgovorite iskreno i objektivno. Zaokružite jedan od ponuđenih odgovora, koji smatrate da je tačan. Za popunjavanje Upitnika imate na raspolaganju 35 minuta.

Unapred hvala na saradnji!

Naziv škole:

Razred:

Pol:

(m)

$(\check{z})$

Uspeh ostvaren u prethodnoj školskoj godini:

Stepen obrazovanja majke:

Stepen obrazovanja oca:

1. osnovna škola

1. osnovna škola

2. srednja škola

2. srednja škola

3. viša i visoka

3. viša i visoka

4. magistratura

4. magistratura

5. doktorat

5. doktorat 
Tekst, koji je primer za 1. pitanje

„Mnogi ljudi veruju da se dovoljno kreću. Istraživanja pokazuju da tek svaki drugi stanovnik Srbije svakodnevno pešači 30 minuta, i to prilikom odlaska do posla i povratka sa posla."

1. Iz navedenog odlomka može se zaključiti:

a) Stanovnici Srbije svakodnevno pešače 30 minuta;

b) Stanovnici Srbije se dovoljno kreću;

c) Stanovnici Srbije se nedovoljno kreću;

d) Nijedan od ponuđenih odgovora;

e) $\mathrm{Ne}$ znam.

$\underline{\text { Red vožnje, koji je primer za 2. pitanje }}$

\begin{tabular}{|c|c|}
\hline \multicolumn{2}{|c|}{ Linija 62: SR. KARLOVCI DUDARA } \\
\hline $\begin{array}{l}\text { Smer A: Polasci za } \\
\text { SR. KARLOVCI DUDARA: }\end{array}$ & $\begin{array}{c}\text { Smer B: Polasci iz } \\
\text { SR. KARLOVCI DUDARA: }\end{array}$ \\
\hline $\begin{array}{l}\mathbf{0 8}^{50} \\
\mathbf{1 0}^{1050} \\
\mathbf{1 1}^{50} \\
\mathbf{1 2}^{15 \text { Đ } 40} \\
\mathbf{1 3}^{20} \\
\mathbf{1 4}^{051540} \\
\mathbf{1 5}^{153045} \\
\mathbf{1 6}^{35} \\
\mathbf{1 7}^{3055} \\
\mathbf{1 8}^{25} \\
\mathbf{1 9}^{15}\end{array}$ & $\begin{array}{l}\mathbf{0 8}^{10} \\
\mathbf{0 9}^{30} \\
\mathbf{1 0}^{50} \\
\mathbf{1 1}^{30} \\
\mathbf{1 2}^{3555 \boldsymbol{D}} \\
\mathbf{1 3}^{20} \\
\mathbf{1 4}^{0545} \\
\mathbf{1 5}^{0030} \\
\mathbf{1 6}^{001030} \\
\mathbf{1 7}^{20} \\
\mathbf{1 8}^{1040} \\
\mathbf{1 9}^{0535 \text { Đ5 } 55}\end{array}$ \\
\hline \multicolumn{2}{|c|}{ Đ = NE SAOBRAĆA ZA VREME ĐAČKOG RASPUSTA } \\
\hline
\end{tabular}

2. Vožnja autobusom od Sremskih Karlovaca do Novog Sada traje 30 minuta. Ako 14. jula 2015. treba da stignete na stanicu u Novom Sadu da biste predali jedan paket tačno u 13.30 i želite što manje da čekate na stanici, izabraćete:

a) Autobus koji kreće u 12.35;

b) Autobus koji kreće u 12.55;

c) Autobus koji kreće u 12.40;

d) Autobus koji kreće u 12.15;

e) Ne znam.

Tekst koji je primer za 3. pitanje

„U neoliberalnom poretku, koji najizdašnije nagrađuje samoživost i pohlepu, religija nudi ne samo prekopotreban moralni kompas nego i adekvatnu zamenu za red koji policija ne želi ili nije u stanju da održava i pravdu koje odavno nema u korumpiranim sudovima." 


\section{Pojam religija u navedenom odlomku se odnosi na:}

a) Policiju;

b) Neoliberalni poredak;

c) Red i pravdu;

d) Nijedan od ponuđenih odgovora;

e) $\mathrm{Ne}$ znam.

\section{$\underline{\text { Tekst koji je primer za 4. i 5.pitanje }}$}

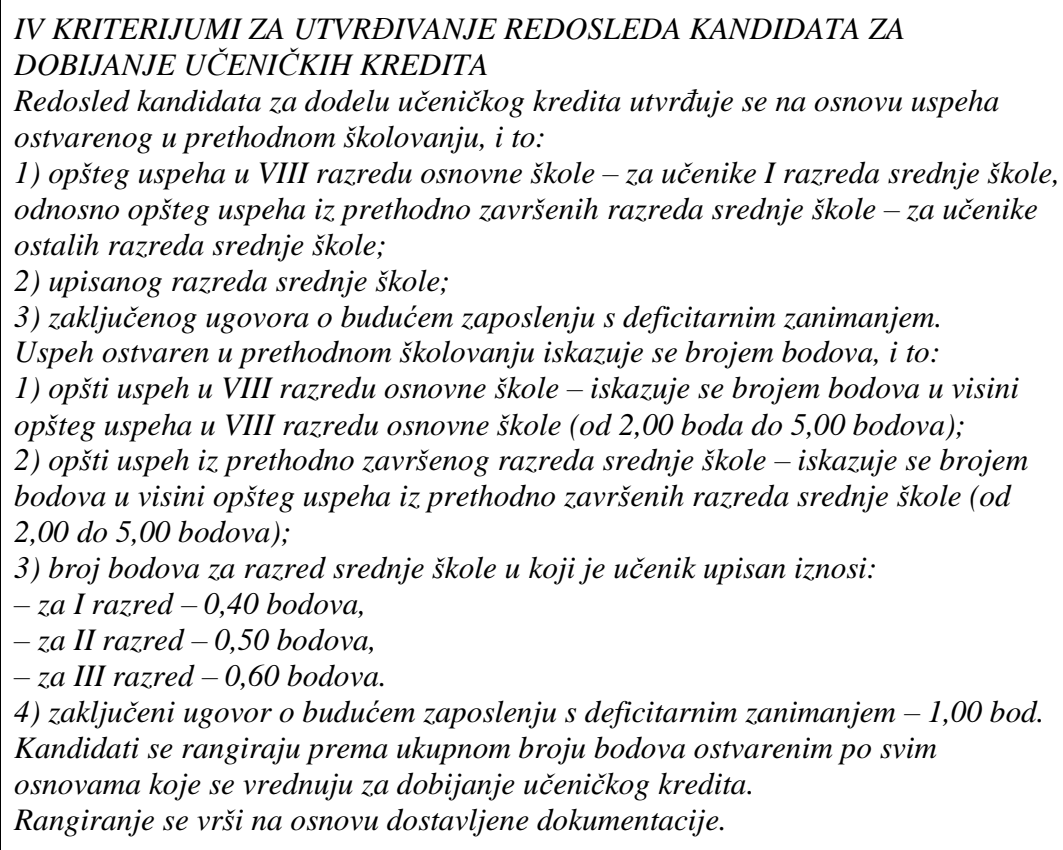

4. Prilikom dodeljivanja učeničkih kredita, imajući u vidu kriterijume koji su iskazani u tekstu, odličan učenik sa najvišim mogućim prosekom koji upisuje treći razred srednje škole i nema ugovor o budućem zaposlenju, imaće:

a) 15,60 poena;

b) 16,60 poena;

c) 10,60 poena;

d) 15 poena;

e) Ne znam.

5. Prilikom dodeljivanja učeničkih kredita za učenike koji upisuju prvi razred srednje škole koji nemaju zaključen ugovor o budućem zaposlenju, boduje se:

a) Uspeh ostvaren u poslednja četiri razreda osnovne škole;

b) Opšti uspeh u VIII razredu osnovne škole;

c) Ukupan uspeh iz svih razreda prethodno završene osnovne škole;

d) Uspeh tokom upisanog prvog razreda srednje škole;

e) Ne znam. 
Tekst koji je primer za 6. pitanje

„Međutim, ako se pozorište, kao mesto stalne aktivnosti, bori samo za svoj puki opstanak, onda stoji u mestu, atrofira, gubi snagu na nominalno, a ne suštinsko održanje. Nema mogućnosti ni za pravi radni zamah, ni za umetnički rezultat. Drugim rečima, pozorište umire uspravno, ali neumitno."

6. Glavna tema u navedenom odlomku je:

a) Odumiranje pozorišta;

b) Radna atmosfera u pozorištu;

c) Aktivnost u pozorištu;

d) Nijedan od ponuđenih odgovora;

e) Ne znam.

$\underline{\text { Statistički podaci, koji su primeri za 7. i 8. pitanje }}$

\begin{tabular}{|c|c|c|c|c|c|c|c|c|c|c|c|c|}
\hline & \multicolumn{2}{|c|}{ Popis 2011.} & \multicolumn{2}{|c|}{ Popis 2002.} & \multirow{2}{*}{$\begin{array}{l}\text { Porast/ } \\
\text { pad }\end{array}$} & & & \multicolumn{2}{|c|}{ Popis 2011.} & \multicolumn{2}{|c|}{ Popis 2002.} & \multirow{2}{*}{$\begin{array}{l}\text { Porast/ } \\
\text { pad }\end{array}$} \\
\hline & ukupno & $\%$ & ukupno & $\%$ & & & & ukupno & $\%$ & ukupno & $\%$ & \\
\hline R. Srbija & 7186862 & 100 & 7498001 & 100 & -31113 & \multicolumn{2}{|c|}{ Muslimani } & 22301 & 0.31 & 19503 & 0.26 & 2798 \\
\hline Srbi & 5988150 & 83.32 & 6212838 & 82.86 & -22468 & \multicolumn{2}{|c|}{ Nemci } & 4064 & 0.06 & 3901 & 0.05 & 163 \\
\hline Albanci & 5809 & 0.08 & 61647 & 0.82 & -5583 & \multicolumn{2}{|c|}{ Romi } & 147604 & 2.05 & 108193 & 1.44 & 39411 \\
\hline Aškalije & 997 & 0.01 & 584 & 0.01 & 41 & \multicolumn{2}{|c|}{ Rumuni } & 29332 & 0.41 & 34576 & 0.46 & -5244 \\
\hline Bošnjaci & 145278 & 2.02 & 136087 & 1.81 & 919 & \multicolumn{2}{|c|}{ Rusi } & 3247 & 0.05 & 2588 & 0.03 & 659 \\
\hline Bugari & 18543 & 0.26 & 20497 & 0.27 & -195 & \multicolumn{2}{|c|}{ Rusini } & 14246 & 0.20 & 15905 & 0.21 & -1659 \\
\hline Bunjevci & 16706 & 0.23 & 20012 & 0.27 & -330 & \multicolumn{2}{|c|}{ Slovaci } & 52750 & 0.73 & 59021 & 0.79 & -6271 \\
\hline Vlasi & 35330 & 0.49 & 40054 & 0.53 & -472 & \multicolumn{2}{|c|}{ Slovenci } & 4033 & 0.06 & 5104 & 0.07 & -1071 \\
\hline Goranci & 7767 & 0.11 & 4581 & 0.06 & 318 & \multicolumn{2}{|c|}{ Turci } & 647 & 0.01 & 522 & 0.01 & 125 \\
\hline Grci & 725 & 0.01 & 572 & 0.01 & 15 & \multicolumn{2}{|c|}{ Ukrajinci } & 4903 & 0.07 & 5354 & 0.07 & .451 \\
\hline Egipćani & 1834 & 0.03 & 814 & 0.01 & 102 & \multicolumn{2}{|c|}{ Hrvati } & 57900 & 0.81 & 70602 & 0.94 & -12702 \\
\hline Jevreji & 787 & 0.01 & 1158 & 0.02 & -37 & \multicolumn{2}{|c|}{ Cincari } & 243 & 0.00 & 293 & 0.00 & -50 \\
\hline Jermeni & 222 & 0.00 & - & - & & \multicolumn{2}{|c|}{ Crnogorci } & 38527 & 0.54 & 69049 & 0.92 & -30522 \\
\hline Jugosloveni & 23303 & 0.32 & 80721 & 1.08 & -5741 & \multicolumn{2}{|c|}{ Česi } & 1824 & 0.03 & 2211 & 0.03 & -387 \\
\hline Mađari & 253899 & 3.53 & 293299 & 3.91 & -3940 & \multicolumn{2}{|c|}{ Šokci } & 607 & 0.01 & 717 & 0.01 & -110 \\
\hline Makedonci & 22755 & 0.32 & 25847 & 0.34 & -309 & \multicolumn{2}{|c|}{ Šopi } & 142 & 0.00 & - & - & . \\
\hline \multirow{2}{*}{$\begin{array}{l}\text { Maternji } \\
\text { jezik }\end{array}$} & \multicolumn{3}{|c|}{2002} & \multicolumn{3}{|c|}{2011} & \multirow{2}{*}{$\begin{array}{c}\text { Indeks } \\
\text { promene } \\
2011 / 2002\end{array}$} & & & & & \\
\hline & $\mathrm{brc}$ & & $\%$ & $b_{r}$ & & $\%$ & & & & & & \\
\hline Ukupno & \multicolumn{2}{|c|}{7498001} & 100 & & 86862 & \multicolumn{2}{|c|}{$100 \quad 95,9$} & & & & & \\
\hline Srpski & \multicolumn{2}{|c|}{6620699} & 88,30 & & 30919 & 88,09 & 95,6 & & & & & \\
\hline Bosanski & & 4749 & 1,80 & & 38871 & 1,93 & 103,1 & & & & & \\
\hline Mađarski & & 6508 & 3,82 & & 43146 & 3,38 & 84,9 & & & & & \\
\hline Romski & & 2242 & 1,10 & & 00668 & 1,40 & 122,4 & & & & & \\
\hline Ostalo & & 3803 & 4,98 & & 73258 & 5,20 & 99,85 & & & & & \\
\hline
\end{tabular}

7. Prema podacima popisa iz 2002. i 2011. godine koji su priloženi, može se zaključiti da je:

a) Do najvećeg porasta broja stanovnika došlo kod one grupe ispitanika koji se izjašnjavaju kao Srbi;

b) Do najvećeg porasta broja stanovnika došlo kod one grupe ispitanika koji se izjašnjavaju kao Bošnjaci;

c) Do znatnog porasta broja stanovnika došlo kod one grupe ispitanika koji se izjašnjavaju kao Egipćani;

d) Do zanemarljivog porasta broja stanovnika došlo kod one grupe ispitanika koji se izjašnjavaju kao Cincari;

e) $\mathrm{Ne}$ znam. 
8. Iz priloženih podataka, može se, takođe, zaključiti da 2011. godine:

a) Najmanji broj ispitanika navodi mađarski jezik kao maternji u odnosu na ukupan broj stanovnika koji su se izjasnili kao Mađari;

b) Najmanji broj ispitanika navodi srpski jezik kao maternji u odnosu na ukupan broj stanovnika koji su se izjasnili kao Srbi;

c) Najmanji broj ispitanika navodi romski jezik kao maternji u odnosu na ukupan broj stanovnika koji su se izjasnili kao Romi;

d) Najmanji broj ispitanika navodi bosanski jezik u odnosu na ukupan broj stanovnika koji su se izjasnili kao Bošnjaci;

e) Ne znam.

Tekst koji je primer za 9. pitanje

„Čuo sam lak uzdah, a onda mi srce stade, prestade da bije od jednog ushićenog i užasnog krika, od krika neopisivog trijumfa i neizrecivog bola. „Znala sam to bila sam ubeđena!" ...Ona je znala. Bila je ubeđena. Čuo sam je kako plače; pokrila je lice rukama. Činilo mi se da će se kuća srušiti pre nego što meni pođe za rukom da pobegnem, da će mi se nebo sručiti na glavu... Ali ništa se ne dogodi. Nebesa ne padaju na takve tričarije."

9. Kakav je odnos pripovedača prema ženskoj osobi?

a) Sažaljeva je;

b) Divi joj se;

c) Ironičan je;

d) Nijedan od ponuđenih odgovora;

e) $\mathrm{Ne}$ znam.

Tekst koji je primer za 10. i 11. pitanje

Dokumenta potrebna za prijavljivanje na Konkurs:

Prijavni list (dobija se na Fakultetu / odeljenju Fakulteta na dan konkurisanja);

- Svedočanstva sva četiri razreda (foto-kopija/original);

- Diploma o stečenom srednjem obrazovanju (foto-kopijaloriginal);

- Izvod iz matične knjige rođenih bez obzira na datum izdavanja (fotokopija/original);

Dokaz o uplati troškova za organizovanje prijemnog ispita.

Foto-kopije ne moraju biti overene, ako se podnesu originalna dokumenta na uvid.

Kandidat ima pravo da se prijavi na najviše tri studijska programa, pri čemu je dužan da polaže prijemne ispite za sve odabrane studijske programe (ako su prijemni ispiti različiti, tada kandidat plaća cenu svakog prijemnog ispita). Ako se polaže matematika sa testom sklonosti za upis više oblasti, polaže se matematika i za svaku oblast test sklonosti (test sklonosti se plaća $50 \%$ za svaku proveru).

Na prijavnom listu kandidat se opredeljuje za osnovnu želju (1) i navodi spisak ostalih želja po prioritetu $(2,3)$. Prijavni list se predaje na šalteru Studentske službe Fakulteta / odeljenju Fakulteta gde je naznačena osnovna želja kandidata, na dan prijave, odnosno u amfiteatrima Fakulteta, ako bude tako određeno. 
10. Nakon pročitanog obaveštenja u vezi sa prijemnim ispitom na fakultetu, može se zaključiti da:

a Kandidat mora da podnese i foto-kopiju i original svedočanstava i diplome srednje škole;

b) Kandidat može da podnese ili foto-kopiju ili original ukoliko je foto-kopija overena;

c) Kandidat mora da podnese i original i overenu foto-kopiju svedočanstava i diplome srednje škole;

d) Kandidat može da podnese samo svedočanstva srednje škole ili samo diplome;

e) $\mathrm{Ne}$ znam.

11. Ukoliko kandidat ne uspe da se upiše na smer koji je naveo kao prioritetni u listi želja:

a) Naknadno polaže prijemne ispite ili ispite sklonosti za smerove koje je naveo kao alternativne;

b) Automatski se upisuje na drugi ili treći navedeni alternativni smer ukoliko je ostvario dovoljno bodova;

c) Može se upisati na drugi ili treći alternativni smer ukoliko je položio odgovarajuće ispite sklonosti ili prijemni ispit za te smerove i stekao dovoljno bodova;

d) Može pisati molbu da bude primljen na smerove koje je naveo kao alternativne;

e) Ne znam.

\section{Tekst koji je primer za 12. pitanje}

„Današnje teniske loptice su žutozelene boje, ali nekada su bile drugačije. Pre toga, one su bile bele ili crne, u zavisnosti od podloge na kojoj se igralo. „Optička žuta” se koristi jer je dokazano da je ona druga najuočljivija boja loptice, bez obzira na vrstu podloge i uslove u kojima se igra. Kada bi se teniske loptice pravile prema naučnim činjenicama, ovi rekviziti bili bi narandžaste boje. Međutim, od toga se odustalo zato što se ne bi dobro videle na televizijskim ekranima."

\section{Zaokružite tačnu informaciju koju ste dobili iz teksta.}

a) Nauka predočava da je „optička žuta” najuočljivija boja teniske loptice;

b) Ostali teniski rekviziti su narandžaste boje;

c) „Optička žuta” se najbolje vidi na televizijskim ekranima;

d) Nijedan od ponuđenih odgovora;

e) $\mathrm{Ne}$ znam.

Tekst koji je primer za 13. pitanje

„U današnje vreme hiperinformativnosti zatrpani smo provokativnim sadržajima $i$ senzacionalizmom do te mere da smo postali inferiorni prema njima. Razvio se jedan obrnuto proporcionalni odnos - što je provokacije više, odgovora na nju je sve manje. Toliko oštrimo sečivo da smo ga otupeli."

\section{Kako razumete poslednju rečenicu u datom odlomku?}

a) Da smo postali agresivni;

b) Da smo postali ravnodušni;

c) Da smo postali povodljivi;

d) Nijedan od ponuđenih odgovora;

e) $\mathrm{Ne}$ znam 
$\underline{\text { Tekst koji je primer za 14. pitanje }}$

4.1. Terapijske indikacije
Lek Claritine je indikovan za simptomatsko lečenje alergijskog rinitisa i hronične
idiopatske urtikarije.

\subsection{Doziranje i način primene}

Odrasli i deca starija od 12 godina:

$10 \mathrm{mg}$ jednom dnevno $(10 \mathrm{mg}=10 \mathrm{ml}$ sirupa jednom dnevno $)$.

Sirup se može uzimati bez obzira na vreme obroka.

Kod dece od 2 godine do 12 godina doziranje se određuje prema telesnoj masi:

Deca telesne mase veće od $30 \mathrm{~kg}: 10 \mathrm{mg}$ jednom dnevno $(10 \mathrm{mg}=10 \mathrm{ml}$ sirupa jednom dnevno).

Deca telesne mase $30 \mathrm{~kg}$ ili manje: $5 \mathrm{ml}(5 \mathrm{mg})$ sirupa jednom dnevno.

Efikasnost i bezbednost leka Claritine kod dece mlađe od 2 godine nije utvrđena.

Pacijenti sa teškim oštećenjem jetre treba da prime manju početnu dozu leka jer mogu imati snižen klirensloratadina. Odraslima i deci telesne mase veće od $30 \mathrm{~kg}$ preporučuje se početna doza od $10 \mathrm{mg}$ svaki drugi dan, dok se deci telesne mase $30 \mathrm{~kg}$ ili manje preporučuje početna doza od $5 \mathrm{ml}(5 \mathrm{mg})$ svaki drugi dan.

Nije potrebno prilagođavati doze kod starijih pacijenata i pacijenata sa renalnom insuficijencijom.

14. Ukoliko se nađete u situaciji da morate da uzmete lek protiv alergijske reakcije koji imate kod sebe, a nemate lekara u blizini, na osnovu datih uputstava, razumećete da:

a) Broj tableta koje ćete uzeti tokom dana zavisi od vaše težine;

b) Početna doza leka koju ćete uzeti treba da bude manja, a zatim da se poveća;

c) Ukoliko nemate utvrđenih bolesti jetre, možete uzeti jednu tabletu;

d) Vreme kada ćete uzeti lek ne sme da se poklapa s vremenom obroka;

e) $\mathrm{Ne}$ znam.

\section{$\underline{\text { Tekst koji je primer za 15. i 16. pitanje }}$}

„Toga novembarskog dana stigla je na levu obalu reke dugačka povorka natovarenih konja i zaustavila se da tu konači. Janjičarski aga, sa oružanom pratnjom, vraćao se za Carigrad, pošto je po selima istočne Bosne pokupio određen broj hrišćanske dece za adžami-oglan."

\section{Najznačajnija informacija u tekstu je:}

a) Mesto gde se povorka zaustavila;

b) Ko je sve bio u povorci;

c) Koji zadatak povorka ima;

d) Nijedan od ponuđenih odgovora;

e) $\mathrm{Ne}$ znam.

\section{Zaokružite tačnu informaciju iz teksta.}
a) Povorka se zaustavila radi ručka;
b) Povorka je prešla most;
c) Povorka se vraćala u Carigrad;
d) Nijedan od ponuđenih odgovora;
e) Ne znam. 
$\underline{\text { Red letenja za Njujork, koji je primer za 17. pitanje }}$

\begin{tabular}{|c|c|c|c|}
\hline & Vreme poletanja & Vreme sletanja & Cena \\
\hline \multirow[t]{2}{*}{1.} & 06:40 Beograd & 19:03 Njujork & 295.002 din \\
\hline & \multicolumn{3}{|c|}{ Trajanje putovanja 18:23/Vreme čekanja 01:45 u Parizu i 01:50 u Atlanti } \\
\hline \multirow[t]{2}{*}{2.} & 06:40 Beograd & 20:00 Njujork & 295.002 din \\
\hline & \multicolumn{3}{|c|}{ Trajanje putovanja 19:20/Vreme čekanja 01:45 u Parizu i 02:40 u Atlanti } \\
\hline \multirow[t]{2}{*}{3.} & 06:40 Beograd & 13:11 Njujork & $334.884 \mathrm{din}$ \\
\hline & \multicolumn{3}{|c|}{ Trajanje putovanja 12:31 / Vreme čekanja 01:20 u Parizu } \\
\hline \multirow[t]{2}{*}{4.} & 06:40 Beograd & 15:16 Njujork & $334.884 \mathrm{din}$ \\
\hline & \multicolumn{3}{|c|}{ Trajanje putovanja 14:36 / Vreme čekanja 00:45 u Parizu i 01.35 u Londonu } \\
\hline \multirow[t]{2}{*}{5.} & 06:40 Beograd & 17:18 Njujork & $334.884 \mathrm{din}$ \\
\hline & \multicolumn{3}{|c|}{ Trajanje putovanja 16:38 / Vreme čekanja 01:30 u Parizu i 01.44 u Detroitu } \\
\hline 6. & 06:40 Beograd & 17:32 Njujork & $334.884 \mathrm{din}$ \\
\hline & \multicolumn{3}{|c|}{ Trajanje putovanja 16:52 / Vreme čekanja 01:30 u Parizu i 02.04 u Detroitu } \\
\hline
\end{tabular}

17. Ukoliko treba da izaberete avionsku kartu od Beograda do Njujorka, a osnovni kriterijum vam je dužina trajanja leta, izabraćete opciju:
a) 1 ;
b) 2 ;
c) 3 ;
d) 4 ;
e) Ne znam.

\section{Tekst koji je primer za 18. pitanje}

„DNK i RNK su nukleinske kiseline. Nukleinske kiseline su dugi makromolekuli koji se sastoje od manjih molekula, odnosno nukleotida. DNK, ili dezoksiribonukleinska kiselina, predstavlja biološku mapu s uputstvima koja jedan živi organizam mora da sledi kako bi nastavio da postoji i funkcioniše. RNK, ili ribonukleinska kiselina, pomaže prilikom sprovođenja ovih uputstava. RNK može da obavlja više funkcija nego DNK, i izvršava mnogobrojne raznovrsne zadatke u organizmu. DNK je, opet, stabilnija i može da čuva kompleksne podatke tokom dugog vremenskog perioda."

\section{U čemu je sličnost između DNK i RNK?}

a) Obe nukleinske kiseline obavljaju više raznovrsnih funkcija u organizmu;

b) Obe nukleinske kiseline predstavljaju biološke mape organizma;

c) Obe nukleinske kiseline se sastoje od nukleotida;

d) Nijedan od ponuđenih odgovora;

e) Ne znam. 
Obrazac koji je primer za 19. pitanje.

\begin{tabular}{|c|c|}
\hline S A G L A S N O S T & (ne treba popunjavati) \\
\hline \multicolumn{2}{|c|}{ 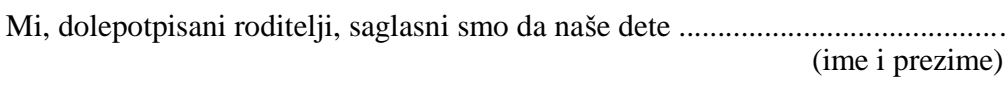 } \\
\hline \multicolumn{2}{|c|}{$\begin{array}{lll}\text { rođatum }) & \text { (mesto rođenja) } & \text { (mesto) }\end{array}$} \\
\hline \multicolumn{2}{|c|}{ ulica } \\
\hline \multirow{2}{*}{\multicolumn{2}{|c|}{$\begin{array}{l}\text { može preći granicu Srbije sa } \\
\text { (ime i prezime - organizacija) } \\
\text { (odredište - država) }\end{array}$}} \\
\hline & \\
\hline \multicolumn{2}{|c|}{ 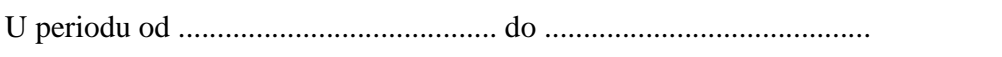 } \\
\hline Otac: & Majka: \\
\hline (Ime i prezime) & (Ime i prezime) \\
\hline (Svojeručni potpis) & (Svojeručni potpis) \\
\hline (Adresa iz ličnog dokumenta) & (Adresa iz ličnog dokumenta) \\
\hline (Broj lične karte MUP) & (Broj lične karte MUP) \\
\hline (JMBG) & (JMBG) \\
\hline
\end{tabular}

19. Radi odlaska na ekskurziju, učenici su dobili obrazac koji za maloletne učenike treba da ispune roditelji. Učenica Marija Marković (JMBG 0201997805023):

a) Ne mora da ima saglasnost roditelja;

b) Trebalo bi da upiše svoje ime i svoj JMBG;

c) Ne treba da popuni obrazac, već to treba da učine njeni roditelji;

d) Treba da upiše ime, JMBG i broj lične karte;

e) Ne znam.

Teskt koji je primer za 20. pitanje

„Možemo da se zavaravamo koliko hoćemo, ali otvaranja poglavlja u pregovorima sa EU neće biti ukoliko se uspešno ne reanimira briselski dijalog Beograda i Prištine. Troje novih aktera probili su led posle neprospavane noći postigavši dogovor o funkcionisanju pravosuđa na severu pokrajine, ali sante su i dalje tu."

20. Kada autor članka kaže: „troje novih aktera probili su led... ali sante su i dalje tu", on zapravo misli:

a) Da su njihovi odnosi i dalje zamrznuti;

b) Da su ostvarili napredak, ali da ima još prepreka;

c) Da su pregovori bili neuspešni;

d) Nijedan od ponuđenih odgovora;

e) Ne znam. 